\title{
Central Park: Nature, context, and human wellbeing
}

\author{
Daniel M. Haybron
}

\begin{abstract}
This paper considers evidence that social and physical contexts, particularly natural environments, are surprisingly important for human wellbeing. In particular, the pursuit of happiness seems to be less a matter of individual choice than is commonly supposed. These ideas are explored through an examination of New York's Central Park.
\end{abstract}

Keywords: philosophy, wellbeing, well-being, happiness, biophilia, nature, context

\section{$80 \cdot \cos$}

It is a scientific fact that the occasional contemplation of natural scenes of an impressive character... is favorable to the health and vigor of men.

- Central Park architect Frederick Law Olmsted ${ }^{1}$

I've tried to transport this sort of joie de vivre when returning to New York, and upon my arrival at J.F.K. I realize, it's not just about me: I am only the shrimp in the gumbo. I need my bell peppers, celery, file, sausage, my neighbors, my mama, my French quarter denizens. I need other people for this magic.

- Margeaux B. ${ }^{2}$

\section{Introduction}

In happiness, as in so many other things, location is key. Or so I will suggest. In what follows I want to consider the importance of context for the successful pursuit of happiness, and more broadly wellbeing. I will say something of social context, which has gotten the most attention in this regard. But mostly I want to focus on the less-noted significance of physical context, specifically the benefits of proximity to the natural world. These appear to be considerable, and add to the case for thinking about the pursuit of happiness less individualistically, and more as a matter of context, than has been our habit. Central Park will serve as the chief vehicle for these reflections.

This paper is small, and my target large. I make no pretense of establishing these claims conclusively-or even, really, establishing them at all. My aim in what follows is, more modestly, to bring together several provocative lines of evidence and sketch the broad

${ }^{1}$ Olmsted 1993, p. 17, cited in Hartig, Berg et al. 2010.

2 “They Know What It Means," The New York Times, June 12, 2009. 
perspective on human wellbeing they apparently point to. It will be enough if the sketch is sufficiently plausible to merit further investigation. The reader will notice that I make more use of anecdote than is typical for an academic journal, partly because this issue is aimed to reach a broader audience. But anecdotes can have substantive value, calling the reader's attention to important points that otherwise might get overlooked, or bringing unanticipated possibilities to the fore. That seems to me the case here, where the empirical challenges to quantifying the benefits of nature are, to put it mildly, steep. Yes, the anecdotes can be unrepresentative, and the teller less than truthful. If the anecdote is honest, and enough readers find it illuminating, then it has earned its keep.

\section{The park}

If you have ever visited New York City, or moved there from elsewhere, perhaps you recall that feeling when you first set foot on its busy, boiling streets: an electric sense of possibility, energizing you and putting an extra bounce in your step. That's how it was for me, anyway, and still is. I have visited many cities, and none of them has quite that effect. New Orleans likewise has a profound impact on the psyche, but it inserts not so much a bounce as a lazy swing in your gait. It matters where you are, for where you are shapes not just what you do but how you feel and think; indeed it molds your very personality. I'm a different person in New York and New Orleans.

New York in particular has a very odd feature: right there, smack in the middle of some of the most valuable real estate on the planet, they put a park. An enormous park. A park that, among other things, makes it very difficult to get from one part of town to another. (Come to think of it, you could probably fit a couple more subway lines there.) If you consider for a moment what New York conventionally stands for, this is a pretty strange thing to do. In the middle of the most industrious city of the most industrious nation of the most industrious age in the history of the planet, they set aside a huge chunk of land for a bunch of trees and grass. It doesn't make a lot of money, nor does it help many people to realize their ambitions, all of which is to say it doesn't make a lot of sense in New York terms. What's it doing there?

Consider: we could level Central Park, pave it, and carpet it with skyscrapers, effectively trading Green Manhattan for Gray Manhattan. And we could fill that annoying gap between the subway lines. This would bring in loads of cash, create countless jobs, and house legions of people at more affordable rates. I trust that most readers would find such a proposal repellent. But why should there be anything wrong with it?

An obvious thought here is that Green is, to some degree, better for us than Gray: our lives would be impoverished by eliminating most vestiges of the natural world from them. But a deeper point, which I will also suggest, is that good places to live are not simply venues for us to seek out whatever we happen to want; they shape what we want, feel and do, nudging us in countless ways toward sensible ways of living, and away from senseless ways of living. And they give us things that we need, even when we don't entirely recognize the need. Central Park illustrates the limits of individual decision in the pursuit of happiness. And yet we find it at the epicenter of the most individualistic age in human history.

\section{The benefits of contact with nature}

The enjoyment of scenery employs the mind without fatigue and yet exercises it; tranquilizes it and yet enlivens it; and thus, through the influence of the mind 
over the body gives the effect of refreshing rest and reinvigoration to the whole system.

-Frederick Law Olmsted ${ }^{3}$

\subsection{The biophilia hypothesis}

At least one investigation suggests that Central Park is a superb place to work $(n=1)$. The study: one summer I procured a small apartment just a block from the $72^{\text {nd }}$ St. entrance to Central Park. I, being a philosophy graduate student, could spend many hours doing my work in the park, most often under a tree in Strawberry Fields. This tree, significantly, grew just a brief stroll from any number of cafes, restaurants, drinking holes, and-my favorite-a storefront advertising soft-serve ice cream containing something like 12 calories. (Probably a fraud, but my kind of fraud.) Offices don't get much better than that.

I trust no one would be surprised that I should choose to do my reading in the park and not, say, my apartment living room. There are good reasons for this. A large body of evidence indicates that human beings tend to respond positively to natural environments: roughly speaking, contact with nature is good for us. Indeed, according to the 'biophilia' hypothesis first advanced by biologist E.O. Wilson, the love of nature is innate, a product of our evolutionary heritage. Interestingly, some of the evidence originally cited in favor of this theory concerns human landscape preferences, namely that people seem generally to prefer environments resembling the African savanna in which much of our evolutionary history transpired: a good view of wide grassy expanses punctuated by trees and perhaps some water. Central Park, perhaps not coincidentally, resembles an idealized savanna habitat. ${ }^{4}$

Now before laying out further evidence for biophilia, I should immediately head off a nest of worries that such claims tend to provoke. The term 'biophilia' may be less than ideal: it strictly concerns an attraction to living things, though much of the appeal of nature relates to nonliving things (the sea, the sky, stars, mountains, streams...). ${ }^{5}$ It can also seem romantic, obscuring the ways in which nature frightens (biophobia) and disgusts us. But it is no part of biophilia theory that people are primed to love everything in nature: what you most love can also be the source of your greatest pains. Strictly speaking, it is not nature per se that benefits us, but certain aspects of the natural world. The evolutionary claim associated with biophilia generates further controversies that needn't detain us here: what matters for practical purposes is that people benefit from contact with nature. ${ }^{6}$ The evolutionary story is relevant only insofar as it lends this idea some plausibility. Note that the idea that biophilia is innate is sometimes taken by critics to imply a kind of biological determinism. It does not: Wilson himself refers to it as a kind of "biased" or "prepared" learning, whereby humans are biased to acquire an affinity for nature. Whether any given individual actually does so, and what precise shape it takes, may depend on the person's environment. ${ }^{7}$ (That said, it is a good question whether anyone, ever, has exhibited a preference for environments thoroughly stripped of all signs of nature: no greenery, no animals, no sun, no stars, no sky, no fresh breeze...).

\footnotetext{
${ }^{3}$ Olmsted 1993.

${ }^{4}$ Wilson 1984. This feature of Central Park is explicitly noted by Ulrich 1995, which also includes a good overview of biophilia theory in relation to viewing natural landscapes.

${ }^{5}$ It is somewhat misleading, then, to speak of natural environments as "green," as I often do here. "Green spaces," in the relevant sense, need not be green. My personal favorites tend rather to be wet.

${ }^{6}$ Strictly speaking, certain kinds of contact with nature. Sharks, tornados, etc. excepted.

${ }^{7}$ Wilson 1984, pp. 106-9. See also Ulrich 1995, pp. 75-77 for a useful discussion of "prepared learning".
} 
Some readers will wonder what 'nature' means anyway. Is the human realm supernatural? If beaver dams count as part of nature, then why don't human constructions? The notion of nature at work here is indeed vague, and should be regarded as a crude placeholder for some more precisely articulated notion to be revealed through further research. We clearly respond differently to what are intuitively natural versus human environments: there is some distinction to be made here. Perhaps, in the end, we can produce the psychological benefits of nature via carefully crafted artificial environments, so that it is not 'nature' per se that we respond to, but a certain range of perceptual cues. This seems to me unlikely, however. ${ }^{8}$

\subsection{The evidence: a sampler}

So what is the evidence that contact with nature benefits us? The literature here is surprisingly large, so I will only gesture at some of the more representative studies; this is not meant to be a comprehensive literature review. To simplify, I will focus on psychological benefits such as increased happiness or otherwise improved psychological functioning, setting aside other ways in which nature experiences can benefit us: for instance, offering deeply meaningful forms of engagement with matters of independent worth, ${ }^{9}$ the added perspective it can bring toward human life, the cultivation of virtues like modesty, humility or wonder, or the aesthetic goods of contemplating beauty. ${ }^{10}$ I will not commit to any particular conception of happiness here, but use the term broadly to refer to matters of subjective wellbeing, particularly emotional wellbeing. ${ }^{11}$

Much of the literature directly addressing questions of benefit concerns the impact of nature exposures on health. While not directly relevant to questions of happiness, the observed health benefits are plausibly mediated by, or at least associated with, greater emotional wellbeing (stress reduction, etc.). Perhaps the best-known study of this sort, published in Science in 1984, found that gallbladder surgery patients randomly assigned to rooms with a window view of a natural setting (i.e., some trees) had significantly shorter hospital stays (7.96 versus 8.7 days post-op), fewer negative comments about their condition recorded by nurses, fewer minor complications, and had a lower need for painkillers than patients whose windows faced a brown brick wall. ${ }^{12}$ Similarly, a study of Michigan prisoners randomly assigned to cells

\footnotetext{
8 There is reason to doubt that recognizably artificial environments can reproduce the full benefits of nature exposure (see, e.g., Kahn, Severson et al. 2009, Kjellgren and Buhrkall 2010; thanks to an anonymous referee for these references). But it may be that lively urban environments like Manhattan are gratifying precisely because they share certain perceptual features with natural environments. If nothing else, they are much more stimulating and visually interesting than simplified, predictable suburban communities.

9 This seems to me a very important benefit of nature, one that cannot easily, if at all, be reproduced by artificial means. A helpful illustration of the way this might be valuable is Darwall's "Aristotelian thesis," in which a central part of the good life involves appreciative engagement with matters of independent value (Darwall 2002).

${ }^{10}$ I also set aside an interesting body of research on the benefits of "connectedness with nature" or "naturerelatedness" (e.g., Mayer and Frantz 2004, Nisbet, Zelenski et al. 2010). This literature mainly assesses the wellbeing impacts of people's attitudes to, and general sense of connection with, the environment. But the benefits of, say, valuing nature are quite distinct from the benefits of experiencing nature. You might feel a kinship with nature, or value its preservation, without actually having much experience of it (cynics might quip that the latter actually promotes the former). Similarly, the finding that valuing material success may reduce happiness has little or no bearing on whether material success itself reduces happiness (Kasser 2002).

${ }^{11}$ I defend an emotional state theory of happiness in Haybron 2005 and Haybron 2008.

12 Ulrich 1984. Some of the studies I discuss, including this one, could fairly be criticized on one or another count. This study, e.g., only had 46 patients. But most of the effects discussed here have been confirmed by multiple studies, so not much hangs on any particular study. For a good but slightly dated review of research on the health and psychological benefits of nature exposure, see Frumkin 2001. An excellent popular discussion of this literature appears in Louv 2008.
} 
facing either the prison courtyard or rolling farmland found a $24 \%$ higher rate of sick calls among those whose cells faced inward, toward the prison yard. ${ }^{13}$

Other studies directly assess anxiety and stress responses, as well as behavioral impacts of nature. Dental patients, for instance, reported less anxiety and had lower blood pressure when a mural of a nature scene was hung in the waiting room than on days when it was removed. ${ }^{14}$ Immersive nature experiences have been found to increase participants' valuing of 'intrinsic' versus 'extrinsic' aspirations - meaning, roughly, that people seem to become less materialistic and more caring and concerned with inherently rewarding activities when engaged with the natural world. ${ }^{15}$

Cognitive functioning also appears to improve through nature experiences. Performance on tasks like proofreading seems to improve from viewing nature scenes, as does attention, alertness, and focus. ${ }^{16}$ Similarly, children with attention deficit disorder (ADD) focus better, and otherwise show diminished symptoms, following nature-related activities such as camping. ${ }^{17}$

Camping and other immersive activities seem, unsurprisingly, to do more good than does merely having a view of a natural setting. 'Horticultural therapy', for instance-gardeningappears to be useful in helping various populations, including prisoners and psychiatric and cardiac patients. ${ }^{18}$ (One observer reports that gardening in a prison has a "strangely soothing effect" on the prisoners, making "pacifists of potential battlers." ${ }^{19}$ ) Similarly, wilderness experiences have been used to treat a variety of problems, medical and otherwise. Inner-city children, for instance, reported greater wellbeing and self-esteem after attending a rural camp. ${ }^{20}$ Healthy adults who took part in 2 to 4 week wilderness experience programs reported "an increased sense of aliveness, well-being, and energy." 21 In fact a heightened sense of vitality, energy, or 'feeling alive' appears to be quite common among those who engage with nature, as well as improved recovery from fatigue. ${ }^{22}$

Note that even a weeks-long wilderness program is unlikely to reproduce the psychic impact of living close to the land full-time, as humans did for most of their history. Truly to become fully engaged with a natural environment arguably takes months or years. Even those well-acquainted with the local landscape and wildlife may take weeks to fully adjust after being away for very long. Reproducing that experience in a representative sample of the population would not be a trivial task. I will present further evidence of the benefits of nature below, in Section 4.6.

\section{The architecture of happiness ${ }^{23}$}

Suppose nature does make us happier. What follows? The obvious take-home is that we, as individuals, should bear that fact in mind when deciding what to do. We could consider

\footnotetext{
${ }^{13}$ Moore 1981.

${ }^{14}$ Heerwagen 1990.

15 Weinstein, Przybylski et al. 2009.

${ }^{16}$ Hartig, Mang et al. 1991, Cimprich and Ronis 2003, Berman, Jonides et al. 2008, Kaplan and Berman 2010.

17 Faber Taylor, Kuo et al. 2001, Kuo and Faber Taylor 2004, Faber Taylor and Kuo 2009.

${ }^{18}$ For references, see Frumkin 2001.

${ }^{19}$ Neese 1959, cited in Frumkin 2001, p. 236.

${ }^{20}$ Readdick and Schaller 2005.

${ }^{21}$ Greenway 1995, cited in Frumkin and Louv 2009, p. 3. See also Ryan, Weinstein et al. 2010.

22 Ryan, Weinstein et al. 2010

${ }^{23}$ With a tip of the hat to De Botton 2008, though I use 'architecture' more broadly, to refer to the social and physical structure of our environment.
} 
spending more time in parks and other green spaces, or even moving someplace where we'll find more contact with the natural world.

I want to suggest something a bit more radical than that: Not that we should go back to living in the trees. Rather, I suggest that the overwhelming focus in our culture on what individuals can do to make themselves happier is a mistake. There are several reasons for this.

\subsection{The collective pursuit of happiness}

For starters, it doesn't take a genius to figure out that individuals can't make parks, though this rather unremarkable fact gets remarkably little attention in the literature on happiness. Parks are a paradigm case of public goods, along with clean air, national defense, and many other good things that typically require collective action to secure. Some of these things are very important to happiness. Relationships, and social capital more generally, are widely thought to be the most important source of happiness, but there is only so much one person can to do secure them. ${ }^{24}$ It takes a village, as they say, to make a village. You can go sit on your porch, but it won't do you much good if no one stops to chat. If your friends are too busy to play, or you're just tired of making calls to track one down, you get to stay home and watch TV. Some things, perhaps most things worth having, people need to work out together. Central Park was one of them: had forward-thinking citizens and planners not made a point of setting aside a huge swath of real estate for a public green space-in the process limiting individuals' freedom to use that land as they saw fit-there would be no park in which to seek one's happiness. And it would be a lot harder for many people to follow the advice to give themselves a bit of nature.

So while I have emphasized the importance of place for happiness in this paper, places like Central Park need people to make them happen, and even good-old-fashioned nature often requires human effort to preserve. The happiness generated by Central Park is a product not simply of geography but of human choice, notably the inspired choices of landscape architects Frederick Law Olmstead and Calvert Vaux, not to mention the many people whose efforts have sustained the park over the years. Happiness is indeed being pursued here, but the endeavor is not so much about 'me' as we tend to suppose, and more about 'we,' and 'thou.' To a considerable degree, we pursue happiness together, and for each other. ${ }^{25}$

\subsection{Underconsuming nature}

Context matters for another reason: people don't always choose well. How wisely we choose may depend substantially on whether we live in the right sort of environment. There is good reason to think people systematically underconsume nature, for example: we avail ourselves of it too little given the magnitude of its benefits to us. The biophilia literature suggests one reason for this: we benefit more from exposure to the natural environment than we realize. Everyone knows that it's pleasant, but few realize just how extensive its psychic impact is, much of it potent but subtle and easily overlooked. And even when we know it will be good for us, we often forgo opportunities to partake. During my summer living by Central Park, I spent far too little time there, inexplicably choosing more often than not to work in my dark little walk-down instead of Strawberry Field. I suppose the few minutes' walk was just too much aggravation; easier just to remain on the couch. There is no question the days would have been more pleasant, and myself happier, had I taken every opportunity to work in the park. And yet I did not.

\footnotetext{
24 See Helliwell and Putnam 2004, Helliwell, Barrington-Leigh et al. 2010.

${ }^{25}$ See also Thin forthcoming-2012.
} 
There is a new development in one of the outer suburbs of St. Louis. In fact, there are many new developments in the outer suburbs and flood plains of St. Louis. Should you venture out to one of them, you will know you've arrived when you find (a) a proliferation of streets named for trees, and (b) few if any actual trees. You see, most housing built in the United States in the last couple of decades sits on land largely bereft of arboreal matter. A smattering of runty little shrubs, perhaps, but, for the most part, curiously uncontaminated by trees. I suppose it saves developers a little money, not having to work around trees, but really I don't know why this is: for whatever reason, builders seem to mow down every tree in sight before laying down a new homestead. Evidently wise to the strangeness of this arrangement, they frequently compensate by putting trees in the street names. 'Pine Crest': no pines, you can be sure (and probably a gully). 'Oak Lane': nary an acorn in sight.

Down one of these treeless-streets-named-for-trees, at some remove from any other sign of civilization - or nature-you will find a barren cul-de-sac circled by some very large, very nice houses. Not entirely barren, actually: one of those homes boasts, in its back yard, three very tall, perfectly formed coconut trees. In St. Louis? Turns out they're made of metal. These are not inexpensive homes, mind you, and they are chock full of widescreen plasma TVs. The owners have plenty of money. Yet smart people with lots of options regularly choose, quite freely, to buy them, treeless yards and all. If people were willing to spend even a small sum for treessay, the cost of another plasma TV-then builders would, I suspect, refrain from chopping them all down. But apparently homebuyers don't figure trees into the equation.

Just a matter of taste? Not likely. People who already have trees on their property typically quite like them, and will spend considerable sums to keep them healthy. A good shade tree over your deck is worth at least a plasma TV. And those streets have woodsy names for a reason. In all likelihood, it just doesn't occur to most homebuyers that trees make a house more desirable. It took many years before even I, who gets paid to notice such things, realized that my vague sense of disgust at new housing developments owed mainly to the lack of trees, and that good trees add a lot to a home. The failure to figure trees into the home-buying equation is quite understandable, but a mistake nonetheless. ${ }^{26}$ Not wise to what they might be missing, homebuyers don't look for it. And so they settle down to consume their plasma entertainments in the cavernous abodes of Tin Palms.

\subsection{Why needs can outstrip motivation}

I've been suggesting that people might systematically fail to choose what's good for them-in particular, that people might fail to choose nature in proportion to its benefits. You might think this implausible: if human beings really benefit so much from contact with nature, wouldn't we have desires to match? And if we're going to trade in evolutionary arguments, here's one: if we evolved an affinity for nature, wouldn't that include commensurate motivation to seek out nature? In general, you might think, it isn't adaptive for human wellbeing to depend on things that we don't really want. If we didn't want to eat, we'd do very badly indeed.

Call this idea the needs-motives congruency thesis (NMCT): people's motives will tend to reflect what's good for them, or at least what they need. ${ }^{27}$ Even if people don't actually need contact with nature - which I doubt-one might expect NMCT to apply to an allegedly innate tendency like biophilia. In fact it need not, and there's no reason to think NMCT holds as a

\footnotetext{
${ }^{26} \mathrm{I}$ am not suggesting that any particular home purchase is a mistake. The mistake is when people give too little weight to the value that trees add to a home when making the decision. But giving trees due weight is, of course, consistent with buying a treeless home.

${ }^{27}$ I previously discussed this issue in Haybron 2008.
} 
general principle. The reason is simple: there's no selection pressure to desire some benefit if there's nothing the organism can do to make its possession more likely. Early humans who strongly craved connection with the natural world would likely have fared no better than those who did not, for the simple reason that there was nowhere else to go. Similarly, there's good reason to think human immune systems need copious exposure, from an early age, to germs; the exposure helps train them up, and those lacking it are more vulnerable to allergies, asthma, and other diseases. ${ }^{28}$ Humans need dirt, basically, but don't particularly desire it. Why? Our ancestors, presumably, had plenty enough of it; they were filthy. Your choices were Pigpen, and Pigpen. By contrast, those among them who craved fats and sweets were clearly better off: such things were scarce but lavish sources of energy, and the more you could get, the better. So we crave fats and sweets. And that's probably why I ended up making more trips to that ice cream shop than to Central Park, even though I am, and was, pretty sure the latter would have done me a lot more good.

\subsection{Context shapes us}

No one who has closely observed the conduct of the people who visit the Park, can doubt that it exercises a distinctly harmonizing and refining influence upon the most unfortunate and most lawless classes of the city-an influence favorable to courtesy, self-control, and temperance.

-Frederick Law Olmsted ${ }^{29}$

Every human being responds to a connection with nature... People of all kinds love something beautiful and will talk to each other when they see it. They change the way they behave. It changes the way they feel about themselves and each other.

-Lynden Miller ${ }^{30}$

Context matters for a third reason: it shapes our mental lives, and with them our behavior. To a surprising extent, the choices you make depend on the environment in which you make them. Not simply because you include information about the context in your deliberations, though. It's also because the context helps make the deliberator.

Olmsted and Miller observe this about Central Park, and doubtless many readers have noticed this too. New Yorkers take on a different demeanor in the park: quicker to laugh, easier to smile, more open, friendly, and loose. They slow down, soften. They even listen. (Something I wish they would do in expensive concert halls.) Watch or listen to Paul Simon's Concert in the Park, or the Simon and Garfunkel version, and you sense New Yorkers at their best. No doubt someone in the crowd got testy, but it's not easy to picture. You get the sense of a hundred thousand souls connecting with each other, and it is not just the music: the setting is key. A Times Square performance would not have been the same. This is one of the great compensations of an afternoon in the park: you don't just get a rewarding taste of nature; you, yourself, undergo a transformation of consciousness and personality. You soften, and open up both to the natural surrounds and to the now less-strange strangers around you. It is easier to

\footnotetext{
28 This is the "hygiene hypothesis." For a review, see Sheikh and Strachan 2004.

${ }^{29}$ Olmsted and Sutton 1997, p. 96.

30 "Garden designer Lynden Miller says a healthy city needs beautiful parks," by Sarah Goodyear, Grist, November $12,2010$.
} 
connect, or at least feel a connection, with fellow New Yorkers in the park, and as a result you get a welcome respite from the relative loneliness and alienation that often attends city life.

We have always known that human beings are sensitive to their environment. But recent work in psychology suggests that we are far more sensitive than most people realize. The traditional story of human nature in the modern West-call it individualism-paints us as rational, autonomous, agents who properly direct our lives through conscious decision. And thus do we respond to our surrounds: we observe what goes on around us and take that information into account. But the conscious, reasoning self calls the shots. At least ideally, individuals are strongly self-determining.

Not all cultures have seen us this way, however, and growing numbers of researchers are beginning to doubt this picture too. Let's call the contrasting view of human agency and wellbeing contextualism. ${ }^{31}$ Roughly speaking, contextualists maintain that people's lives tend to go best when they are, to a significant extent, shaped by their social and environmental context. In short, people live better given some mix of constraints and assists. Individualists, by contrast, think human lives go best when individuals, as much as possible, determine the shape of their lives. Individualism and contextualism are typically motivated by very different views of human psychological functioning. In particular, individualists normally see autonomous, conscious decision-making as the healthy norm for human action. Whereas contextualists tend to regard much of what we do as quite fittingly shaped by our circumstances, in ways that often bypass conscious choice. For the contextualist, then, the good life will depend substantially on living in the right sort of environment-one that conduces to good choices and otherwise nourishes us. Individualists take the good life to be fundamentally an individual matter, dependent on whether people choose wisely, and perhaps also on whether people have the options to live as they wish. Environments are important, of course - it is better to live in Italy than North Korea-but only because a poor environment can get in the way of the individual's living as she freely chooses.

To an individualist, then, Central Park is a good thing because it gives people something they want. In economists' terms, it is a commodity that individuals can choose, or not, to consume. And when in the park, what people do will depend on their preferences, their deliberations, their personalities.

I am suggesting that individualism - the usual way of looking at things - badly understates the impact of our environment on our psyches. A place like Central Park, for instance, doesn't just satisfy our preferences; it shapes them. It is not simply a venue for making choices; it influences the choice-making process itself, substantially below the radar of consciousness. And it is good, in part, because it makes us better choosers. Indeed, it has a multitude of salutary effects on our functioning more broadly, making us more perceptive, sensitive, and so forth. As well, it benefits us independently of our choices: it makes us happier, even if we don't realize that it does. It gives us something we may not know is good for us. At least, many contexts are like this; while the evidence on Central Park itself is largely anecdotal, the power of situations to influence our functioning in these ways is well-established. It would be surprising, and certainly contrary to my own experience, if Central Park lacked this power.

\subsection{The evidence for contextualism}

These are, clearly, large issues. Here I can only hope to gesture very broadly at the research favoring contextualism. There are roughly two bodies of literature here, the most important of

\footnotetext{
${ }^{31}$ For further discussion of the individualism/contextualism distinction, see Haybron 2008.
} 
which is situationist research in social psychology. ${ }^{32}$ You may already know something of this literature if, say, you've heard of the infamous Milgram obedience experiments, where ordinary citizens were easily gotten to shock innocent test-takers, as far as they could tell, to death. (The shocks, and their effects, were fake.) In this case, a bad situation caused people to violate their most cherished values for trivial reasons. A similar study put college students in a simulated prison, whereupon they promptly adopted the manner of beasts - so rapidly and disturbingly that the experiment had to be terminated early. (The atrocities at Abu Ghraib were entirely predictable to anyone having a passing acquaintance with this research.) Other studies have found that whether people help someone in need is strongly influenced by such weighty matters as: whether they found a dime in a pay phone; whether other people are in the vicinity; whether they just unscrambled words related to helpfulness; whether a lawnmower was running nearby; and so on. ${ }^{33}$ Merely exposed to words related to the elderly, people's memory gets worse and they walk more slowly. Disturbingly, subliminal exposure to pictures of African-American men causes white people to get angrier when their computer subsequently crashes. ${ }^{34}$ Whether people save for retirement often depends on what the default option was on their employment paperwork: if they have to check a box to save, they won't; but if they don't, they will. ${ }^{35}$ And recent work on social networks suggests that many behaviors and feelings ripple through the population like viruses: if you become obese, get divorced, or grow happier, chances are significantly greater that your friends will, too-and their friends, and so on. ${ }^{36}$

The litany of results goes on, but the idea should be plain enough: human beings are extraordinarily sensitive to their environment, so that even tiny situational cues can have large effects on what they do and how they feel. And if even trivial manipulations can strongly impact our behavior, one can imagine the influence that the myriad facets of our physical and social environments have on us. The juiciest studies concern bad influences, so many people wrongly take the moral to be that situations are threats to good choice: we must learn to resist them. But situations can help just as easily as they hurt. Good situations inspire firefighters and soldiers to feats of heroism; entire villages to risk their lives to help the innocent, as happened in France when Le Chambon rescued thousands of Jewish refugees from the Holocaust; and ordinary folks to save more, eat better, exercise more, and lead happier lives. Central Park is a good situation.

The other line of research helps explain why situations are so important. ${ }^{37}$ Specifically, the mistakes noted earlier: a vast body of work shows that human beings are systematically prone to make poor choices in many situations. Let's call these tendencies 'biases,' though I'm not sure all of them can strictly be considered biases (as when our memories are just lousy, but in no particular direction). We put too much weight on losses versus gains; we irrationally favor the status quo; we ignore base rates when estimating probabilities; we are overconfident and

\footnotetext{
${ }^{32}$ Actually, there are three, the third being research on automaticity or "dual process" psychology, which indicates that we have less control over our behavior than we tend to think (Haybron 2008). But this work is mainly relevant insofar as it relates to situationism and mistakes, and for brevity and simplicity I omit it here.

${ }^{33}$ For reviews of the situationist literature discussed to this point, see Doris 2002 and Ross and Nisbett 1991. While situationism is often associated with a controversial skepticism about personality or character traits, my arguments here do not require that strong view, and are compatible with a robust role for personality variables.

${ }^{34}$ For reviews of these and other automaticity findings, see Doris 2009, Bargh and Chartrand 1999, and Hassin, Uleman et al. 2005.

35 Thaler and Sunstein 2008.

${ }^{36}$ Fowler and Christakis 2008. Christakis and Fowler 2007, McDermott, Christakis et al. 2009, Christakis, Fowler et al. 2009.

37 The automaticity literature is also crucial here.
} 
overly optimistic about our futures, and generally think too highly of ourselves; we overestimate the impact of many events on our happiness; our choices irrationally favor 'hard' or quantifiable values over intangibles, even when we consider the 'soft' values more important; we discount our own futures at an insanely steep rate; again, the list could go on for some time. ${ }^{38}$

I don't suppose anyone needs convincing of this in the wake of our recent financial mass suicide attempt, but people make lots of mistakes. We make lots of choices that, by our own lights, are lousy. These mistakes have consequences: think divorce rates, poorly chosen careers, foreclosures, bankruptcies, overeating, under-exercising, meagre savings, credit card debt, underinsurance, and countless hours in front of the television (I have met very few people who actually want to be couch potatoes; they just, as it were, fall into it). Some of this is just bad luck, but a lot of it is error-predictable error. Many economists have been skeptical about such worries, arguing that people are still mostly rational and prudent. Well, yes, that has to be true: imagine what would happen if we were complete buffoons, paying more for the rotten apple than the fresh one, searching for the most expensive gas station we can find, and buying all our clothes the wrong size. We'd starve. But the whole point of Greek tragedy is precisely how few mistakes it takes to ruin your life. Just one will do. The perfectly rational Homo economicus could well be a close approximation to a stupendously imprudent creature.

One reason situations are important, then, is that they can either ameliorate, or exacerbate, our tendencies to make mistakes. (As in the default option bias noted above.) This point, mostly lost on contemporary Western culture, has been obvious to almost every society in human history, where considerable effort has gone into developing social institutions that foster good behavior, and discourage bad. Sometimes this works through coercion or rational persuasion, but more often it takes the form of myriad 'nudges' that simply make certain choices, and certain ways of living, come naturally to people. Think French vs. American eating habits: the French eat fattier foods yet are thinner and live longer. To live in France is to be embedded in an encompassing food culture where eating well is easy, indeed a tremendous source of pleasure. To live in the United States, where the culture follows the tenets of laissez-faire individualism, is to be embedded in an anything-goes food culture where staying healthy requires a constant battle between willpower and appetite. Instructively, willpower regularly loses: one third of America's youth may well become, not just overweight, but diabetic. ${ }^{39}$ (Where I live, doctors sometimes refer to obesity as 'Missouri medium'.)

Taken together, the research on situationism and biases seems to me highly damaging for individualistic views of human agency and wellbeing. Individualists, including many economists, will argue that these effects are mere 'anomalies' afflicting a species for whom conscious, rational deliberation, and a strong form of self-determination, are the healthy norms. They could be right. But I would suggest that a broad shift in our picture of human nature is under way: situation-sensitivity and biases aren't regrettable limitations or anomalies, and they aren't 'bugs.' They are core features of human psychology, and central aspects of healthy human functioning. ${ }^{40}$ Situation-sensitivity does give us Milgram, yes, but it also gives us Le Chambon. Indeed it may be what makes human society possible: for a social species, you want individuals to be highly sensitive to context, rapidly and automatically adjusting themselves in response to the myriad social cues that surround them. You want people to fit in and get along,

\footnotetext{
${ }^{38}$ Accessible reviews of this literature appear in Gilbert 2006, Thaler and Sunstein 2008, Ubel 2009, Trout 2009 and Schwartz 2004. A more academic, but fairly comprehensive, review appears in Haybron 2008.

39 Boyle, Thompson et al. 2010.

${ }^{40}$ See Haybron 2008, chapters. 11-12.
} 
and a race of individuals who do so only when they calculate that it serves their purposes is not likely to do a very good job of it.

And for a hunter species whose survival originally depended on adeptly navigating the natural world, conscious deliberation would likely be a very crude, clumsy tool for many purposes. You want individuals who automatically attune themselves to their environment, responding to the blizzard of information with sensitivity, discernment, and speed. Considering how different the demands of this environment are from those of social life, it would make good sense for the transition between the social and natural worlds to automatically trigger a cascade of psychological changes. Here is Michael Pollan's description of his first attempt at hunting:

Nothing in my experience has prepared me for the quality of this attention. I notice how the day's first breezes comb the needles in the pines, producing a sotto voce whistle and an undulation in the pattern of light and shadow tattooing the tree trunks and the ground. I notice the specific density of the air. But this is not a passive or aesthetic attention; it is a hungry attention, reaching out into its surroundings like fingers, or nerves. My eyes venture deep into thickets my body could never penetrate, picking their way among the tangled branches, sliding over rocks and around stumps to bring back the slenderest hint of movement. In the places too deeply shadowed to admit my eyes, my ears roam at will, returning with the report of a branch cracking at the bottom of a ravine, or the snuffling of a...wait: what was that? Just a bird. Everything is amplified. Even my skin is alert, so that when the shadow launched by the sudden ascent of a turkey vulture passes overhead I swear I can feel the temperature momentarily fall. I am the alert man. ${ }^{41}$

Pollan later notes that "it was as if I'd dialled up the gain on all my senses," a sharp contrast he likened to "putting on glasses with a strong new prescription for the first time." 42 His hunting mentor confirms that this observation about "hunter's eye" was quite typical. He continues, "so much sensory information was coming into my head that it seemed to push out the normal buzz of consciousness. The state felt very much like meditation." 43

Such is the power of context. While toting a .30-06 through Central Park is probably not a good idea, it is not implausible that any time spent in natural environments would trigger wide-ranging psychological changes. The contextualist moral to all this is that, in thinking about human wellbeing, we need to move beyond the typical focus on what individuals can do to make themselves happier. We need to attend closely to the social and environmental context in which people spend their lives, and how that influences their psychologies and behavior. We need to take seriously the architecture of happiness.

\subsection{Greening the architecture of happiness}

What does Central Park tell us about the architecture of happiness? At least, that accessible green spaces are a good thing, not just for the nature experiences they offer but for the social leavening they provide. The question arises, however, whether mere parks are enough: the psychic impact of time in the park appears to last for some time after you leave; and it would not be surprising if that benefit proved to be somewhat contagious, passing even to those who

\footnotetext{
41 Pollan 2007, pp. 334-5.

42 Pollan 2007, p. 341.

43 Pollan 2007, p. 341.
} 
never went. But parks rarely occupy a very sizeable fraction of people's time, and our minimal exposure to parks can only do so much to make us happier. ${ }^{44}$ The question, then, is whether social planning can do more to 'spread the wealth' of contact with nature: can we design green urban environments that offer more continual exposure to nature, even if only in small doses? Can the natural world be part of the fabric of our everyday lives, including the majority of our workdays? Obviously we can't all live in the wilderness. But perhaps smaller steps can be made that would do us all good, spreading a little bit of Central Park throughout our daily environs, and thus, we can hope, promoting happiness and social connection. ${ }^{45} \mathrm{New}$ buildings might incorporate substantial greenery, for instance. And housing construction might transition from low-density treeless suburbs, which isolate residents both from nature and each other, to higher-density communities with abundant shared green space-friendlier to wildlife, healthy child play, and connecting with our neighbors. ${ }^{46}$ Someday, today's synthetic gray office cubicles may be regarded with puzzlement and disgust, the relics of a benighted era.

There is some fairly direct evidence that such measures would yield tangible benefits. ${ }^{47} \mathrm{~A}$ simple expedient like introducing plants to the office, for instance, may reduce blood pressure while increasing efficiency and perceived attentiveness among workers. ${ }^{48} \mathrm{We}$ already noted, similarly, the effects of a window view on hospital patients and prison inmates. On a larger scale, two large epidemiological studies in the Netherlands found proximity to green space to be a significant predictor of health, even controlling for obvious factors like age and socioeconomic status. ${ }^{49}$ Other studies have found that stress declines among residents the closer they live to green spaces, again controlling for obvious factors. ${ }^{50}$ The effects are strongest for people who spend the most time near their residences, like the elderly, housewives, and poorer residents. As well, they seem to be substantially due to psychological benefits from nature exposure, rather than just mediated by physical exercise. Interestingly, frequency of use of green spaces does not fully account for the impact. Perhaps people benefit just from seeing or even knowing about them, or maybe they gain indirectly, through their neighbors.

Let me cite just one more study, or rather series of studies, concerning the Robert Taylor Homes, a low-income housing project in Chicago. ${ }^{51}$ Here, twenty-eight buildings arrayed over three miles housed thousands of residents randomly assigned to apartments. Some of them

\footnotetext{
${ }^{44}$ New Yorkers are not known for their sunny dispositions, Central Park notwithstanding (e.g., Oswald and Wu 2010).

45 There is in fact a minor industry of architecture and urban planning devoted to just such questions. See, e.g., Kellert 2005, Kellert, Heerwagen et al. 2008.

${ }^{46}$ No doubt one reason for the popularity of sprawling suburbs is the relatively plentiful greenery, so the problem is less acute there than in cities. Yet neatly manicured lawns, particularly those without decent trees, may be so transparently artificial that they fail to yield many of the benefits of less tightly managed spaces. (It would be interesting to see a study of wellbeing among suburbanites whose yards are barely distinguishable from astroturf versus those with much "wilder" properties.) As well, private yards don't bring people together in natural environs the way parks do.

${ }^{47}$ For reviews, see Matsuoka and Sullivan 2011 and Sullivan and Chang in press.

${ }^{48}$ Lohr, Pearson-Mims et al. 1996. There is some question, however, about how robust these effects are; see Bringslimark, Hartig et al. 2009.

${ }^{49}$ De Vries, Verheij et al. 2003, Maas, Verheij et al. 2006, Maas, Verheij et al. 2009.

50 Grahn and Stigsdotter 2003, Nielsen and Hansen 2007.

51 See Kuo 2001, Faber Taylor, Kuo and Sullivan 2002, Kuo and Sullivan 2001a, Kuo and Sullivan 2001b. For an accessible discussion, see Frumkin and Louv 2007.
} 
faced trees, grass, and other vegetation, like that pictured here: ${ }^{52}$

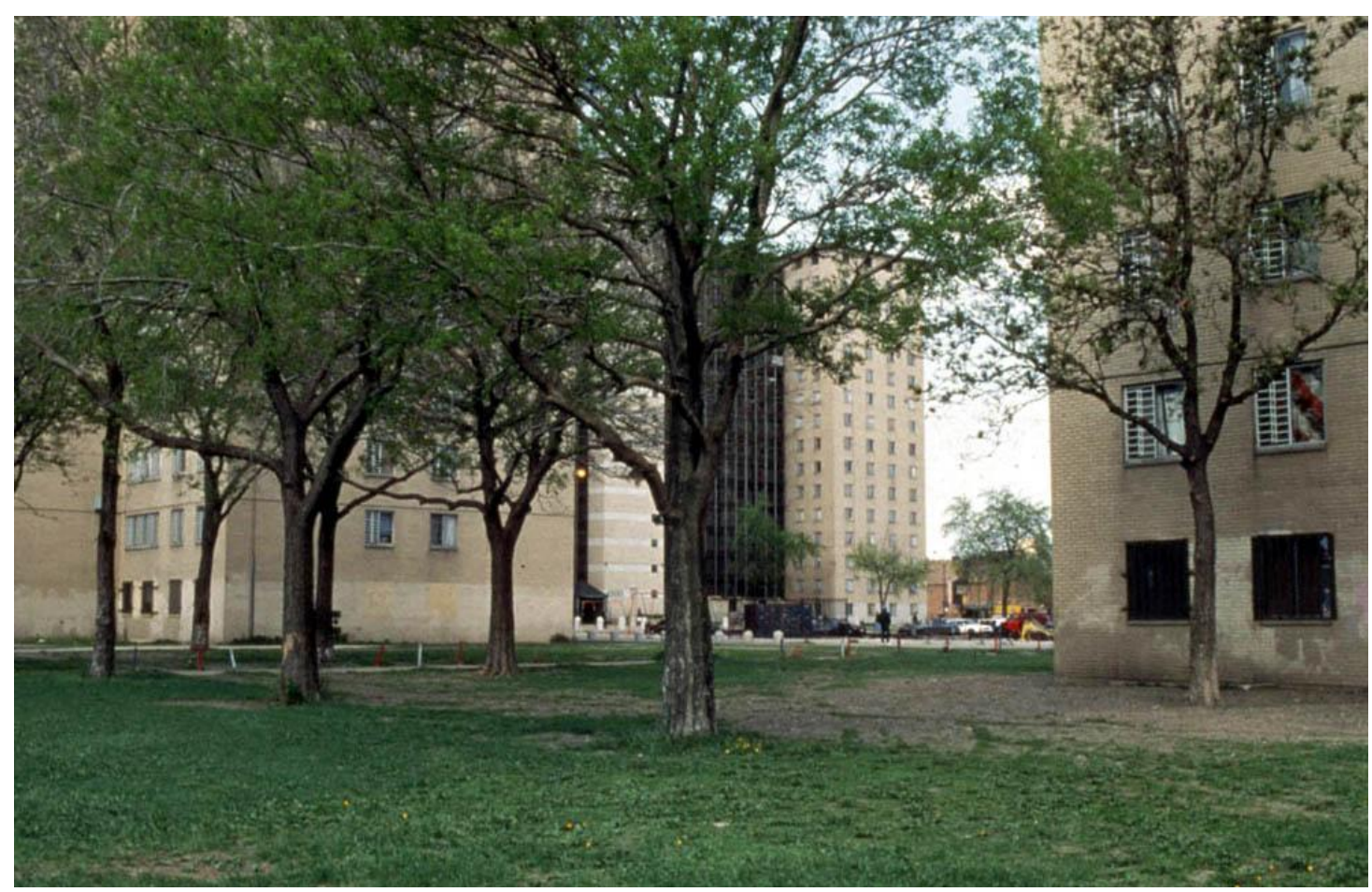

(C) William Sullivan

Other apartments faced, well, something like this charming vista:

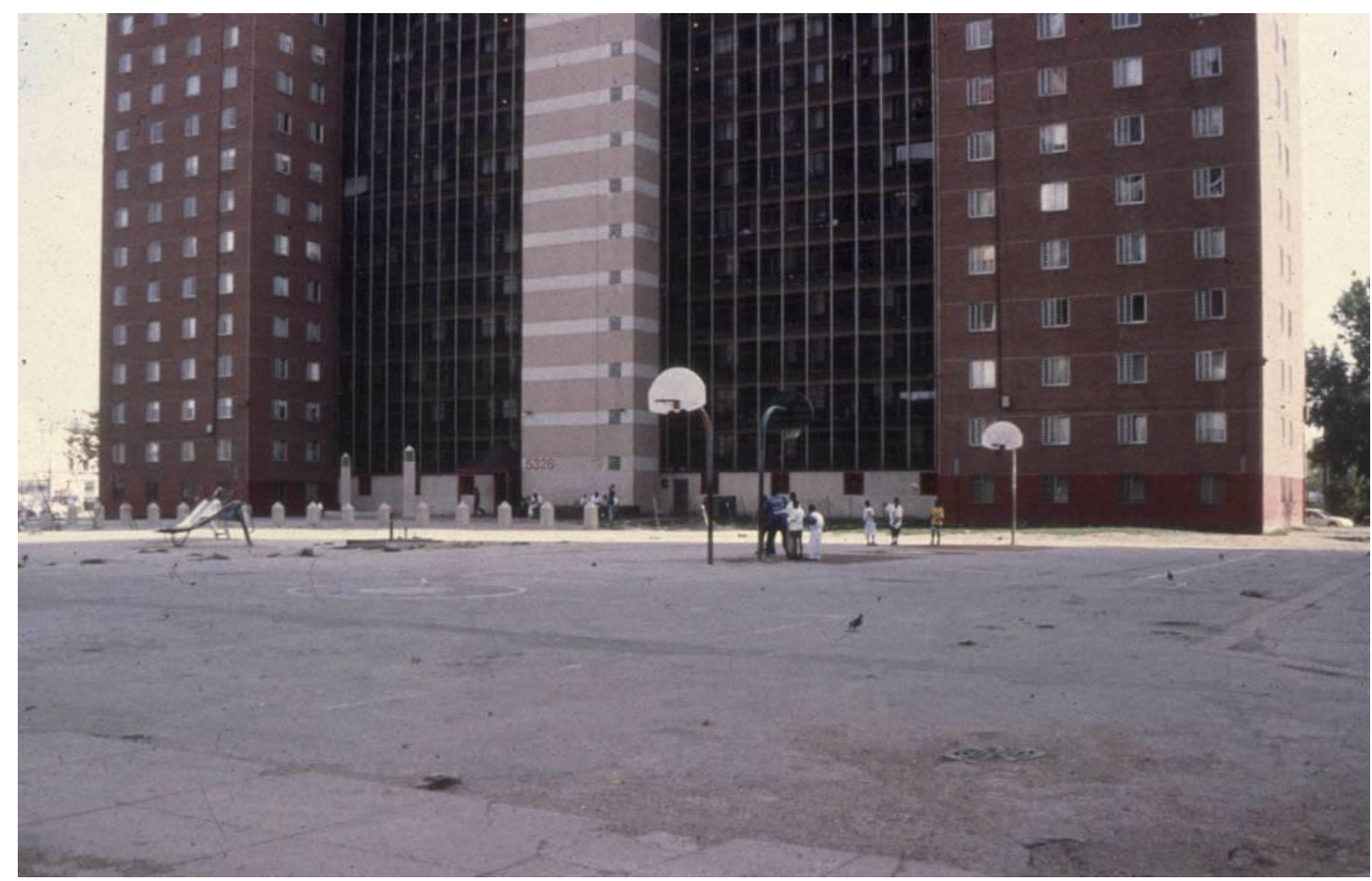

(C) William Sullivan

52 Photographs by William Sullivan; used with kind permission. 
In essence, we have a big experiment in Green versus Gray Manhattan, except that the differences are smaller: nobody enjoyed a Central Park in the vicinity, while everyone had access to some greenery. What did they find? 'Green' apartment dwellers were significantly more likely to know their neighbors, socialize or even know people within their building, acknowledge or help each other, and significantly less likely to engage in a wide range of aggressive behaviors against their partners. For instance, nearly half of the 'Grays' employed "severe violence" against their partners within the past year, while only (!) thirty-one percent of Greens did. ${ }^{53}$ As well, Greens procrastinated less, saw their problems as less severe, had better coping skills and self-discipline, and-obviously-had better relationships and committed fewer crimes. These are not effete nature-lovers, note, but hard people leading hard lives. It would not be surprising if most of them had no idea the greenery made any difference to their wellbeing-a nice frill, perhaps, but nothing important. And it would be very surprising if many of the residents fully recognized how much they could benefit from even the barest whiff of nature. In fact, only seven percent of participants mentioned anything remotely related to vegetation when asked what they looked for in a place to live, and only one participant said that a 'natural setting' was important. Like the citizens of Tin Palms, they probably underestimate the value of contact with the natural world. ${ }^{54}$ Look at that second picture. Kind of makes you want to hit someone, doesn't it? In an interview, investigator Frances Kuo reported, "Without vegetation, people are very different beings." 55

I suspect many people would agree that nature is good for us, but regard it as merely a question of optimizing: if not a luxury, then pretty far down the list of social desirables. I would conjecture that it is more a matter of maintaining our sanity. ${ }^{56}$

\section{Conclusion}

While the immediate lesson of Central Park is that people could benefit from greater connection with nature, there is a broader moral to the story: the pursuit of happiness is not simply an individual affair. This is not to deny the power of individual prudence: we can exert tremendous control over our own happiness, perhaps the best example of this being Buddhist training. ${ }^{57}$ But even Buddhist practice arguably embodies contextualist insights: beginning meditators are advised to practice in formal group settings - at least partly, it seems, because such settings make it easier to take up the discipline; it takes less willpower. Moreover, Buddhist monasteries tend not to be located in dark, filthy basements, though the real estate might be cheaper. Settings and rituals create a suggestive context that conduces to the right mindset. Progress is made, not simply through individual agency, but through agency as shaped by context.

Consider the likelihood of Americans taking up meditation en masse. Even if every citizen were given a manual, and liked what they saw, the odds seem to me vanishingly small that more than a small proportion would, in the short run, commit to the practice. If widespread

\footnotetext{
${ }^{53}$ Kuo and Sullivan 2001a, p. 556. The sample size was 145. "Severe violence" meant at least one of: kicked, bit, or hit with a fist; hit or tried to hit with something; beat up the other one; threatened with a knife or gun; used a knife or gun.

${ }_{54}$ True, they are poor: their responses are eminently understandable. But the results suggest they may, for all that, undervalue nature.

${ }^{55}$ In a documentary film, The Forest Where We Live, by Louisiana Public Broadcasting. Cited in Tina Prow, "The

Power of Trees," The Illinois Steward, 7:4, Winter 1999.

${ }^{56}$ For a further example of how these are not merely the concerns of rich Westerners, consider the Brazilian city of Curitiba, which is well-known for making green space and environmental concerns a top priority.

57 Ricard 2006.
} 
meditation is to become a reality, it will need to become part of the culture, including institutions that create a setting in which meditating seems natural, and not unusual or weird. This could happen from the bottom-up, as forward-thinking individuals influence acquaintances to take up meditation and the practice spreads like a virus. Or it could happen from the top-down, for instance if the military were to incorporate meditation into training, sending many thousands of respected, mainstream meditators back into the culture. ${ }^{58}$ Even for Buddhists, the pursuit of happiness is not typically something we undertake alone.

I will close by returning to the most obvious contextualist good: sociality. Human beings are intensely social animals. Some commentators, Aristotle included, have even likened us to bees and herd animals. Be that as it may, researchers generally agree that human relationships, both personal and communal, are the most important source of happiness. Social isolation is immensely destructive, as the fate of prisoners in solitary confinement-many of them go crazy - makes plain. 59 'All you need is love,' though exaggerated, is close enough to the truth that it is trite even to mention it.

Let me venture a somewhat radical suggestion: short of securing vital physical needs like survival and freedom from severe pain, no gains in other goods could compensate for large decreases in our connections with other people. A society that creates mass social isolation in exchange for other goods that aren't vital needs is almost certainly making a grave mistake, and the happiness of its residents will be greatly compromised. Some contemporary societies, arguably, are doing just this. The basic worry is familiar enough, so I will offer just one data point: a large-scale epidemiological study in the United States finds that the average American can claim just two confidants-relatives or friends with whom they can discuss important matters. And a quarter of Americans have none. ${ }^{60}$ These figures reflect a significant decline in social connection compared to results from twenty years prior. If you ran those numbers by the inhabitants of most societies through human history, I imagine a lot of jaws would drop. I submit that no quantity of plasma TVs, SUVs, iPods, luxury cruises, or inflatable shoes could make this a reasonable, or even sane, development. Surely this isn't the necessary price of antibiotics and a steady supply of food. If those numbers are correct, then we are very likely talking about a profoundly sick society. ${ }^{61}$

This is not a problem individuals can solve on their own, and giving people still more choices is not going to make it go away. Indeed, part of the problem may be that we have so many options, many of which don't require other people. Perhaps the problem is insoluble, one of the unavoidable discontents of civilization. But I don't think so: even today, in some corners of the modern world, there remain places where friendship and neighborly affection are abundant, where evenings are passed in the company of friends and not a glowing screen, where music is something people make together and don't merely consume through headphones, and where being 'grounded' might constitute a meaningful punishment for a

\footnotetext{
${ }^{58}$ My Buddhist friends might well shudder at such an idea, which probably isn't particularly faithful to Buddhism. But it could well do a lot of good, reducing both atrocities and psychological trauma among soldiers. In any event, meditative practice need not be embedded in Buddhist doctrine.

${ }^{59}$ Smith 2006. See also Cacioppo, Hawkley et al. 2003, Cacioppo and Hawkley 2009, Miller 2011.

${ }^{60}$ McPherson, Lovin-Smith et al. 2006.

${ }^{61}$ It may be objected that most people are in fact happy, so there can't be much of a problem here. I've argued at length elsewhere that people are probably a good deal less happy than much of the research seems to suggest (Haybron 2007, 2008). It is possible that a majority of people are happy, but we aren't currently in a position to say. Suffice it to say that rates of happiness are almost certainly lower than is often claimed, and rates of psychological distress are in some cases rather alarming. In any event, everyone agrees that the vast majority of people are less happy than they could be, and most researchers think it would be desirable for people to be happier.
} 
child. They have TVs and all the rest, but they don't let the stuff get between the people. These places exist, not because they are pockets of specially wise individuals, but because the local landscape and culture make them possible. Front porches and walkable neighborhoods help, ${ }^{62}$ as do trees and common green spaces. So do unspoken customs of time allocation: a simple expectation that you'll hang out when the day's work is done, or when a neighbor stops to say hello. More familiar markers of culture also play a role: a shared pool of songs everyone can sing, or norms against dining alone.

If you happen to live in such a place, and are blessed as well with green surrounds, you'll likely be a lot happier than if you reside in an anonymous, gray cityscape whose residents beat a daily retreat to their well-appointed isolation chambers. But you probably won't be able to claim credit for it.

\section{Author}

Daniel M. Haybron

Saint Louis University

haybrond@slu.edu

\section{Publishing Timeline}

Received 31 January 2011

Accepted 11 April 2011

Published 20 July 2011

\section{References}

Bargh, J. A. and T. L. Chartrand (1999). "The unbearable automaticity of being." American Psychologist 54(7), pp. 462-479. http://dx.doi.org/10.1037/0003-066X.54.7.462

Berman, M., J. Jonides and S. Kaplan (2008). "The cognitive benefits of interacting with nature." Psychological Science 19(12), pp. 1207-1212.

Boyle, J., T. Thompson, E. W., Gregg, L. E., Barker and D. F., Williamson. (2010). “Projection of the year 2050 burden of diabetes in the US adult population: dynamic modeling of incidence, mortality, and prediabetes prevalence." Population Health Metrics 8(1), pp. 29. http://dx.doi.org/10.1186/1478-7954-8$\underline{29}$

Bringslimark, T., T. Hartig and G. G. Patil. (2009). “The psychological benefits of indoor plants: A critical review of the experimental literature." Journal of Environmental Psychology 29(4), pp. 422-433. http://dx.doi.org/10.1016/j.jenvp.2009.05.001

Cacioppo, J. and L. Hawkley (2009). "Perceived social isolation and cognition." Trends in Cognitive Sciences 13(10), pp. 447-454.

Cacioppo, J., L. Hawkley and G. Berntson (2003). “The anatomy of loneliness." Current Directions in Psychological Science 12(3), pp. 71-74.

Christakis, N. and J. Fowler (2007). "The spread of obesity in a large social network over 32 years." New England Journal of Medicine 357(4), pp. 370. http://dx.doi.org/10.1056/NEJMsa066082

Christakis, N. and J. Fowler (2009). Connected: The surprising power of our social networks and how they shape our lives. New York: Little, Brown and Co.

Cimprich, B. and D. Ronis (2003). "An environmental intervention to restore attention in women with newly diagnosed breast cancer." Cancer Nursing 26(4), pp. 284.

Darwall, S. (2002). Welfare and Rational Care. Princeton: Princeton University Press.

De Botton, A. (2008). The Architecture of Happiness. New York: Vintage Books.

\footnotetext{
${ }^{62}$ Rogers, Halstead et al. 2010.
} 
De Vries, S., R. Verheij, P.P. Groenewegen and P. Spreeuwenberg. (2003). “Natural environments-healthy environments? An exploratory analysis of the relationship between greenspace and health." Environment and planning A 35(10), pp. 1717-1732. http://dx.doi.org/10.1068/a35111

Doris, J. M. (2002). Lack of Character. New York: Cambridge University Press.

Doris, J. M. (2009). “Skepticism about persons.” Philosophical Issues 19(1), pp. 57-91. http://dx.doi.org/10.1111/j.1533-6077.2009.00159.x

Faber Taylor, A. F. and F. Kuo (2009). "Children with attention deficits concentrate better after walk in the park." Journal of Attention Disorders 12(5), pp. 402. http://dx.doi.org/10.1177/1087054708323000

Faber Taylor, A. F., F. E. Kuo, et al. (2001). "Coping with ADD.” Environment and Behavior 33(1), pp. 54.

Faber Taylor,A. F., F. E. Kuo and W. C., Sullivan (2002). “Views of nature and self-discipline: evidence from inner city children." Journal of Environmental Psychology 22(1-2), pp. 49-63. http://dx.doi.org/10.1006/jevp.2001.0241

Fowler, J. and N. Christakis (2008). “Dynamic spread of happiness in a large social network: longitudinal analysis over 20 years in the Framingham Heart Study." British Medical Journal 337(dec04 2), pp. a2338-a2338. http://dx.doi.org/10.1136/bmj.a2338

Frumkin, H. (2001). "Beyond toxicity: Human health and the natural environment." American Journal of Preventive Medicine 20(3), pp. 234-240.

Frumkin, H. and R. Louv (2007). “The powerful link between conserving land and preserving health." Land Trust Alliance Special Anniversary Report. Available at: http://atfiles.org/files/pdf/FrumkinLouv.pdf

Gilbert, D. (2006). Stumbling on Happiness. New York: Knopf.

Grahn, P. and U. Stigsdotter (2003). "Landscape planning and stress." Urban Forestry E Urban Greening 2(1), pp. 1-18. http://dx.doi.org/10.1078/1618-8667-00019

Greenway, R. (1995). "The wilderness effect and ecopsychology." Ecopsychology: Restoring the Earth, Healing the Mind. San Francisco: Sierra Club Books, pp. 122-135.

Hartig, T., A. van den Berg, C. M. Hagerhall, M. Tomalak, N. Bauer, R. Hansmann, A. Ojala, E. Syngollitou, g. Carrus, A. van Herzele, S. Bell, M. T. Camilleri Podesta and G. Waaseth (2010). "Health Benefits of Nature Experience: Psychological, Social and Cultural Processes." Forests, Trees and Human Health, pp. 127-168.

Hartig, T., M. Mang and G. W. Evans (1991). "Restorative effects of natural environment experiences." Environment and Behavior 23(1), pp. 3. http://dx.doi.org/10.1177/0013916591231001

Hassin, R. R., J. S. Uleman and J. A. Bargh (2005). The New Unconscious. New York: Oxford.

Haybron, D. M. (2005). “On Being Happy or Unhappy.” Philosophy and Phenomenological Research 71(2), pp. 287-317.

Haybron, D. M. (2007). “Do We Know How Happy We Are?” Nous 41(3), pp. 394-428. http://dx.doi.org/10.1111/j.1468-0068.2007.00653.x

Haybron, D. M. (2008). The Pursuit of Unhappiness: The Elusive Psychology of Well-Being. New York: Oxford University Press.

Heerwagen, J. H. (1990). “The psychological aspects of windows and window design.” In Proceedings of the 21st Annual Conference of the Environmental Design Research Association, eds. R. I. Selby, K. H. Anthony, J. Choi and B. Orland. Oklahoma City, OK: Environmental Design Research Association, pp. 269-280.

Helliwell, J. F., C. P. Barrington-Leigh, A. Harris and H. Huang (2010). “International Evidence on the Social Context of Well-Being." In International Differences in Well-Being, eds. E. Diener, J. F. Helliwell and D. Kahneman. New York: Oxford University Press. http://dx.doi.org/10.1093/acprof:oso/9780199732739.003.0010

Helliwell, J. F. and R. Putnam (2004). "The Social Context of Well-Being." Philosophical Transactions of the Royal Society 359(1449), pp. 1435-1446. http://dx.doi.org/10.1098/rstb.2004.1522

Kahn, P., R. Severson and J. H. Ruckert (2009). "The human relation with nature and technological nature." Current Directions in Psychological Science 18(1), pp. 37-42. 
Kaplan, S. and M. Berman (2010). “Directed Attention as a Common Resource for Executive Functioning and Self-Regulation." Perspectives on Psychological Science 5(1), pp. 43-57. http://dx.doi.org/10.1177/1745691609356784

Kasser, T. (2002). The High Price of Materialismm. Cambridge, Mass.: MIT Press.

Kellert, S. (2005). Building for Life: Designing and Understanding the Human-Nature Connection. Washington, DC: Island Pr.

Kellert, S., J. Heerwagen and m. Mador (2008). Biophilic Design: The Theory, Science, and Practice of Bringing Buildings to Life. Hoboken, NJ: Wiley.

Kjellgren, A. and H. Buhrkall (2010). "A comparison of the restorative effect of a natural environment with that of a simulated natural environment." Journal of Environmental Psychology 30(4), pp. 464-472.

Kuo, F. (2001). "Coping with Poverty- Impacts of Environment and Attention in the Inner City." Environment and Behavior 33(1), pp. 5-34. http://dx.doi.org/10.1177/00139160121972846

Kuo, F. and A. Faber Taylor (2004). "A potential natural treatment for attention-deficit/hyperactivity disorder: evidence from a national study." American Journal of Public Health 94(9), pp. 1580. http://dx.doi.org/10.2105/AJPH.94.9.1580

Kuo, F. and W. Sullivan (2001a). "Aggression and violence in the inner city." Environment and Behavior 33(4), pp. 543. http://dx.doi.org/10.1177/00139160121973124

Kuo, F. (2001b). "Environment and crime in the inner city." Environment and Behavior 33(3), pp. 343.

Lohr, V., C. Pearson-Mims and G. K. Goodwin (1996). "Interior plants may improve worker productivity and reduce stress in a windowless environment." Journal of Environmental Horticulture 14, pp. 97-100.

Louv, R. (2008). Last Child in the Woods: Saving Our Children from Nature-Deficit Disorder. Chapel Hill, NC: Algonquin Books.

Maas, J., R. Verheij, S. de Vries, P. Spreeuwenberg, F., G. Schellevis and P., P. Groenewegen (2009). "Morbidity is related to a green living environment." Journal of Epidemiology $\mathcal{E}$ Community Health 63(12), pp. 967-973. http://dx.doi.org/10.1136/jech.2008.079038

Maas, J., R. A. Verheij, P. Groenewegen, S. de Vries and P. Spreeuwenberg (2006). “Green space, urbanity, and health: how strong is the relation?" Journal of Epidemiology and Community Health 60(7), pp. 587.

Matsuoka, R. and W. Sullivan (2011). "Urban nature: Human psychological and community health.” In The Routledge Handbook of Urban Ecology, eds. I. Douglas, D. Goode, M. Houck and R. Wang. Oxford: Taylor and Francis, pp. 408-423.

Mayer, F. and C. Frantz (2004). “The connectedness to nature scale: A measure of individuals' feeling in community with nature." Journal of Environmental Psychology 24(4), pp. 503-515.

McDermott, R., Fowler, J. H. and Christakis, N. A., Breaking Up is Hard to Do, Unless Everyone Else is Doing it Too: Social Network Effects on Divorce in a Longitudinal Sample Followed for 32 Years (October 18, 2009). Available at SSRN: http://ssrn.com/abstract=1490708

McPherson, M., L. Smith-Lovin and M. E. Brashears (2006). "Social Isolation in America: Changes in Core Discussion Networks over Two Decades." American Sociological Review 71(3), pp. 353-375. http://dx.doi.org/10.1177/000312240607100301

Miller, G. (2011). “Why Loneliness Is Hazardous to Your Health.” Science 331(6014), pp. 138-140. http://dx.doi.org/10.1126/science.331.6014.138

Moore, E. (1981). "A prison environment's effect on health care service demands." Journal of Environmental Systems 11(1), pp. 17-34.

Neese, R. (1959). “Prisoner's escape." Flower Grower 46(8), pp. 39-40.

Nielsen, T. and K. Hansen (2007). "Do green areas affect health? Results from a Danish survey on the use of green areas and health indicators." Health $\mathcal{E}$ Place 13(4), pp. 839-850.

http://dx.doi.org/10.1016/j.healthplace.2007.02.001

Nisbet, E., J. Zelenski and S. A. Murphy (2010). "Happiness is in our Nature: Exploring Nature Relatedness as a Contributor to Subjective Well-Being." Journal of Happiness Studies, pp. 1-20.

Olmsted, F. (1865). "The Yosemite Valley and the Mariposa big trees: a preliminary report, 1865." Landscape Architecture 43(1), pp. 12-25. 
Olmsted, F. and S. Sutton (1997). Civilizing American Cities: Writings on City Landscapes. New York: Da Capo Press.

Oswald, A. J. and S. Wu (2010). “Objective Confirmation of Subjective Measures of Human Well-Being: Evidence from the U.S.A." Science (New York, NY) 327(5965), pp. 576-579. http://dx.doi.org/10.1126/science.1180606

Pollan, M. (2007). The Omnivore's Dilemma. New York: Penguin.

Readdick, C. A. and G. R. Schaller (2005). "Summer camp and self-esteem of school-age inner-city children." Perceptual and Motor Skills 101(1), pp. 121-130. http://dx.doi.org/10.2466/pms.101.1.121-130

Ricard, M. (2006). Happiness: A Guide to Developing Life's Most Important Skill. New York: Little, Brown and Co.

Rogers, S., J. Halstead and K. Gardner (2010). “Examining Walkability and Social Capital as Indicators of Quality of Life at the Municipal and Neighborhood Scales." Applied Research in Quality of Life, pp. 113.

Ross, L. and R. E. Nisbett (1991). The Person and the Situation: Perspectives of Social Psychology. Philadelphia: Temple University Press.

Ryan, R., N. Weinstein, J. Bernstein, K. Warren Brown, L. Mistretta and M. Gagné (2010). “Vitalizing effects of being outdoors and in nature." Journal of Environmental Psychology 30(2), pp. 159-168.

Schwartz, B. (2004). The Paradox of Choice. New York: Harper Collins.

Sheikh, A. and D. P. Strachan (2004). "The hygiene theory: fact or fiction?" Current Opinion in Otolaryngology \& Head and Neck Surgery 12(3), pp. 232-236.

Smith, P. (2006). "The effects of solitary confinement on prison inmates: A brief history and review of the literature." Crime \& Justice 34, pp. 441.

Sullivan, W. C. and C.-Y. Chang (in press). "Mental Health." In Making Healthy Places: A Built Environment for Health, Well-Being, and Sustainability, eds. A. L. Dannenberg, H. Frumkin and R. J. Jackson. Washington, DC: Island Press.

Thaler, R. H. and C. R. Sunstein (2008). Nudge: Improving Decisions about Health, Wealth, and Happiness. New Haven: Yale University Press.

Thin, N. (forthcoming-2012). Social Happiness: Evidence and Arguments for Collective Life Improvement. Bristol: Policy Press.

Trout, J.D. (2009). The Empathy Gap: Building Bridges to the Good Life and the Good Society. New York: Viking Press.

Ubel, P. (2009). Free Market Madness: Why Human Nature is at Odds with Economics - and Why it Matters. Boston: Harvard Business School Press.

Ulrich, R. (1984). "View through a window may influence recovery from surgery." Science 224(4647), pp. 420-421.

Ulrich, R. (1995). "Biophilia, biophobia, and natural landscapes." In The Biophilia Hypothesis, eds. S. R. Kellert and E. O. Wilson. Washington, DC: Island Press, pp. 73-137.

Weinstein, N., A. Przybylski and R., M. Ryan (2009). “Can Nature Make Us More Caring? Effects of Immersion in Nature on Intrinsic Aspirations and Generosity." Personality and Social Psychology Bulletin 35(10), pp. 1315-1329. http://dx.doi.org/10.1177/0146167209341649

Wilson, E. O. (1984). Biophilia. Cambridge, MA: Harvard University Press. 